\title{
ALGUNOS MODELOS ESCÉNICOS E ICONOGRÁFICOS EN TRES ESCENOGRAFÍAS PARA LA FÁBULA DE ANDRÓMEDA Y PERSEO SEGÚN PIO DI SAVOIA, CORNEILLEY CALDERÓN
}

Teresa Chaves

Doctora en Historia del Arte Via Francesco Grimaldi, 151

00146, Roma (Italia)

chavesit@yahoo.it

[Anuario calderoniano (ISSN: 1888-8046), vol. extra, 1, 2013, pp. 49-81]

La fábula de Andrómeda y Perseo gozó de una singular fortuna en la historia del espectáculo teatral barroco ya que fue una de las más representadas en los escenarios de las cortes europeas en forma de comedia, melodrama, intermedios, tragedia, ópera-torneo, etc., durante los últimos años del siglo XVI y todo el XVII. La preferencia por las vicisitudes de estos dos personajes mitológicos por parte de dramaturgos, escenógrafos, promotores y público puede obedecer a distintas razones, aunque ninguna de ellas la justificaría de manera contundente. Es cierto que las aventuras del hijo de Júpiter y Dánae, es decir, Perseo, y la princesa etíope (según Ovidio), esto es, Andrómeda, destinada a morir entre las fauces de un monstruo marino y su salvación a manos del joven semidiós, se prestaban idealmente a todo un despliegue de efectos escénicos, como eran las mutaciones en los distintos decorados de palacio, ciudad, marina, jardín y templo, donde se desarrolla- 
ban dichas aventuras, y las tramoyas empleadas para los vuelos de Perseo, los carros aéreos que trasladaban a los dioses o la lucha contra el feroz 'cetáceo', es decir, todos esos efectos que tanto gustaban al público de la época. Pero también es cierto que, por el mismo motivo, había otros muchos argumentos inspirados en Las Metamorfosis ovidianas que podían provocar la misma maravilla entre los espectadores. Otra hipótesis sugerida ha sido la de la utilización de la imagen de Perseo como alegoría de la virtud — según Boccaccio, entre otros autores, en su Genealogía de los dioses paganos-, así como también otras interpretaciones recientes hacen referencia a una posible relación entre esta figura y el poder, es decir, Perseo, héroe valiente de origen divino, como encarnación del príncipe, y sus gestas gloriosas, como reflejo de las de éste último ${ }^{1}$. Evidentemente todos son motivos que ayudaron a su difusión iconográfica y escénica, pero sin duda uno de los que cobran más fuerza es la tradicional interpretación caballeresca del mito y las similitudes de sus empresas con las llevadas a cabo por los caballeros andantes. Recordemos en este sentido los frecuentes paralelismos establecidos entre la liberación de Andrómeda por Perseo y la de Angélica por Ruggiero y las contaminaciones recíprocas de sus respectivas iconografias a la hora de ser representadas no sólo en la escena sino también en la pintura y en las estampas que ilustraban algunas ediciones tanto de Las Metamorfosis de Ovidio como del Orlando furioso de Ariosto ${ }^{2}$.

Citaré a continuación algunos ejemplos de cómo se escenificó la fábula de Perseo y Andrómeda en algunos teatros europeos y las posibles afinidades o diferencias más notables que se pueden encontrar en cuanto a la forma de representarla, según también el género de espectáculo al que se circunscribía. Los primeros son dos representaciones en Florencia, muy próximas en cuanto a fechas, y a las que se han atribuido unas imágenes que, aunque no haya ninguna certeza documental, podrían ajustarse o corresponder a alguna de estas pues-

1 Brown, 1988, p. 107; Ruiz de Elvira, 1988, pp. 159 y 303-304; Portús Pérez, 1989; López Torrijos, 1991.

${ }^{2}$ Sobre las influencias recíprocas entre las fábulas de Perseo y Orlando y los episodios de las liberaciones de Andrómeda y Angélica así como sus fuentes iconográficas y literarias, ver López Torrijos, 1991. Sobre la iconografia del salvamento de Andrómeda y Perseo a lomos de Pegaso, ver también López Torrijos, 1985, pp. 231242; Portús Pérez, 1989 y Chaves Montoya, 2004, pp. 212-217. 
tas en escena, si no a las dos: en el primer caso se trata de los seis intermedios para una fábula pastoril representada en 1618 en el Palacio de la Gherardesca, en Florencia, escritos por Jacopo Cicognini con escenografia y máquinas de Cosimo Lotti. Aunque no se han conservado explícitamente dibujos o estampas con las escenas de estos intermedios, gracias a la descripción de las mutaciones que hizo el compositor Giulio Caccini se ha apuntado una posible relación de cuatro bocetos preparatorios de Jacques Callot, conservados en los Uffizi, con esta "fábula marítima» ${ }^{3}$, ya que se ajustaban perfectamente a dicha descripción [Figura 1].

Estos dibujos también se han relacionado con la puesta en escena de otra obra que tampoco llegó a imprimirse, el Perseo de Alessandro Adimari, de fecha posterior aunque incierta, pero, en cualquier caso, anterior a 1621, año en que Callot dejó la corte florentina. Este dato estaría además avalado por la proximidad de dichas pruebas de estampa y la escena del quinto intermedio con la liberación de Andrómeda, que Adimari describe como un decorado de bastidores laterales en forma de rocas, el mar en medio y la joven atada a un peñasco que avanza hacia el centro de la escena ${ }^{4}$. Para el montaje de este Perseo de Adimari, destinado al Teatro Mediceo, en los Uffizi, parece bastante probable que se reutilizaran decorados ya existentes en el teatro, según una respetada y repetida política de economía no sólo de materiales sino también, por lo visto, de ideas, pues todas las escenas de esta fábula recuerdan, en la iconografía y la disposición de los decorados, a numerosos ejemplos, anteriores y posteriores, de otros espectáculos del mismo escenario. De aquí que los dibujos de Callot destinados a la estampa pudieran relacionarse tanto con la obra de Cicognini como con la de Adimari.

Caccini también afirmaba que Lotti se había inspirado en pasados espectáculos del Teatro Mediceo a la hora de crear la escenografía y las tramoyas de los intermedios de 1618, según esa costumbre tan asentada en las fiestas teatrales de la corte del Gran Duque e igualmente extendida en las del resto de Europa. Por ejemplo, para el tercer intermedio de la Andromeda de Cicognini, Lotti habría echado mano del quinto de La Pellegrina (1589), con El rescate de Arión [Figura 2], una

3 Gaeta Bertelà y Petrioli Tofani, 1969, pp. 170-172.

${ }^{4}$ Mamone, 1996, p. 540; Chaves Montoya, 2004, p. 29. 
escena marina en la que aparecía Anfitrite rodeada de tritones, una imagen muy difundida gracias a la estampa de Epifanio d'Alfiano, de 1592, a partir del dibujo de Bernardo Buontalenti, autor de la escenografia, y que en los siguientes decenios inspiraría tantos decorados marinos incluso fuera de Italia ${ }^{5}$.

En los carnavales de 1638, Ascanio Pio di Savoia y Francesco Guitti, escenógrafo al servicio de las cortes de Parma y Ferrara, crearon la ópera-torneo titulada L'Andromeda, escenificada en la Sala de las Comedias del Palacio Ducal de Ferrara: el primero, Pio di Savoia, como autor del texto y director escénico, y el segundo, Guitti, como escenógrafo y autor de las máquinas. El año siguiente, 1639, fue editado el libreto con la descripción de la acción, las escenografias y las máquinas, redactada por Ignazio Trotti, y el texto de la ópera, ilustrado con 15 grabados del propio Francesco Guitti reproduciendo los momentos más significativos de la acción y, sobre todo, las apariciones de los dioses en máquinas aéreas o en carros marinos en las cuatro escenas (marina, bosque, ciudad y palacio).

La escena marina del prólogo, aún próxima al grabado de Alfiano ${ }^{6}$, servirá de marco a la liberación de Andrómeda, en la segunda parte de la ópera. El grabado de Guitti [Figura 3] representa el momento en el que Palas, invocada por Andrómeda encadenada a un escollo, llega en un carro dorado tirado por dos lechuzas, mientras se aproxima Perseo sobre Pegaso en medio de vuelos y piruetas que dejaron suspendidos los ánimos del público: «El caballo» —escribía Trotti«batía las alas, y se estiraba admirablemente por el aire, haciendo mil volteretas y movimientos bizarros, que dejaban abstraídas las vistas, y las almas confusas; y además estaba tan bien hecho, y reflejaba tan bien el natural, que añadía al estupor un extremo placer al que lo miraba» ${ }^{7}$.

La estampa siguiente [Figura 4] recoge, casi como un fotograma, el proseguimiento de la acción, cuando de las aguas de un «mar insólito e impetuoso» sale un gran 'cetáceo' con el cuerpo cubierto de

${ }^{5}$ Bolduc, 2002, p. 41; Strong, 1988, p. 138.

${ }^{6}$ Bolduc, 2002, p. 57.

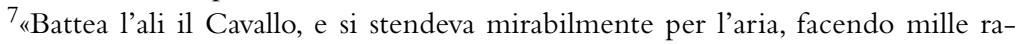
vvolgimenti, e moti bizarri, che lasciavano astratte le viste, e gli animi confusi Era poi a parte a parte così ben formato, e tanto espresso al naturale, che aggiungeva allo stupore un'estremo diletto in chi lo mirava». Ver Pio di Savoia, L'Andromeda, p. 66. 
escamas, ojos de fuego, la enorme boca abierta y un aspecto aterrador, el cual, sumergiéndose y surgiendo de entre las olas, se iba acercando a Andrómeda. Perseo, después de unos cuantos vuelos alrededor del monstruo, y, siempre ante la maravilla de los espectadores - que se preguntaban cómo era posible que estuviera suspendido en el aire y se moviera con tanta agilidad-, descubre la cabeza de Medusa que llevaba oculta con un velo carmesí para petrificar con su mirada a la ballena cuando esta se disponía a atacar ${ }^{8}$, así como Ruggiero había descubierto un escudo deslumbrante para rematar a la bestia en su operación rescate de Angélica9

El hecho de que esta escena se retrotrajera a modelos iconográficos de cincuenta años atrás, y a sus referencias más recientes, que se habían estado repitiendo durante todos esos últimos años, no significa que los elementos escénicos y técnicos no hubieran sido actualizados con la aplicación de las más modernas conquistas en materia escenográfica.Y precisamente a un discípulo de Francesco Guitti, Giacomo Torelli, se deberá la codificación y difusión de estas novedades que ya habían puesto en práctica escenógrafos anteriores (entre otros su propio maestro), a partir de Giovan Battista Aleotti, y que consistían en el uso del sistema de bastidores planos, dispuestos paralelamente y deslizables que se desplazaban por las ranuras del tablado y por los raíles del telar, accionados por un sencillo sistema de contrapesos que permitía el cambio global de las escenas ${ }^{10}$.

El arquitecto y escenógrafo italiano, nacido en Fano en 1608, tuvo ocasión de exportar dichas novedades a la corte francesa gracias a la invitación de la regente Ana de Austria. Su debut se produjo en el Hôtel de Bourgogne de París, en 1645, con el montaje de La finta

${ }^{8}$ Ver Pio di Savoia, L'Andromeda, p. 69.

${ }^{9}$ No era la primera vez que Pio di Savoia había utilizado la imagen ariostesca del velo carmesí que oculta un escudo resplandeciente y que se retira en el momento oportuno para deslumbrar al contrincante. La ocasión fueron las bodas de Odoardo Farnese y Margarita de Médicis en 1628, celebradas en Parma con varias representaciones teatrales, entre otras una Aminta con cinco intermedios escritos por Pio di Savoia, el primero titulado Il castello incantato de Atlante, inspirado en un episodio del Orlando furioso. Chaves Montoya, 2006, pp. 187-188.

${ }^{10}$ Bianconi, 2000, p. 77; Bolduc, 2002, p. 57. Para el conjunto de la obra de Giacomo Torelli, ver la monografía de Bjurström, 1962 y, en concreto, para la puesta en escena de Andromède, ver Guarino, 1982. 
pazza. Tal fue el éxito que obtuvo (un milagro ante los ojos del público francés, acostumbrado hasta tiempos muy tardíos a la escena simultánea o decoración múltiple, procedente de la tradición de las mansiones de los misterios medievales, aunque en ellos ya se aplicaran las reglas de la perspectiva escénica), que Mazarino le encargó en 1647 la puesta en escena, en el Palais Cardinal, de la ópera Orfeo ${ }^{11}$, cuyos decorados y máquinas tuvo que adaptar Torelli a una representación de gusto más francés, compuesta por el flamante miembro de la Académie Française, Pierre Corneille. Destinada a los carnavales de 1648, no llegó a estrenarse hasta el 13 de enero de 1650, en la sala del PetitBourbon, modificada para este fin por el propio escenógrafo.

Andromède, título de esta tragédie à machines, supone un caso un poco excepcional en la historia del teatro barroco, debido a su dificil intento por conciliar los cánones, fieles a la verosimilitud, de la tragédie classique, con los del espectáculo de aparato, algo así como un compromiso entre dos tendencias del gusto que, después de esta experiencia, no volverían a encontrarse. Uno de los problemas fundamentales que podía plantear la puesta en escena de esta tragedia (y que en España encontraremos también en las comedias de aparato de $\mathrm{Cal}$ derón) es el de la funcionalidad de la escenografía respecto a la acción dramática y su necesidad al servicio del texto dramático o si, por el contrario, su utilización responde únicamente a una finalidad visual y espectacular. Pero el propio Corneille resolvió las posibles dudas afirmando, en la presentación del argumento, que los decorados y las máquinas eran tan sustanciales para la tragedia que, si faltara alguno de ellos, «se derrumbaría todo el edificio». No se trataba de unos atractivos aislados, añadidos para hacer más agradable el espectáculo, sino que eran "el nudo y el desarrollo» ${ }^{12}$.

Un año después, en 1651, salió la edición impresa de la tragedia con seis grabados de François Chauveau que reflejan el efecto ilusionista y el resultado visual del espectáculo, en una síntesis de la mara-

11 Guarini, 1982, pp. 9-14.

12 "[Les machines] ne sont pas dans cette tragédie comme les agréments détachés, elles en font le nœud et le dénouement, et y sont si nécessaires que vous n'en sauriez retrancher aucune, que vous ne fassiez tomber tout l'édifice». Corneille, Andromède [Argumento], pp. 8-9. 
villa y de los nudos dramáticos principales, con las acotaciones escénicas y la descripción de los decorados y las máquinas ${ }^{13}$.

En el prólogo de Andromède [Figura 5] intervienen la musa de la tragedia, Melpómene, y el Sol, símbolo de la realidad cósmica, que en un diálogo presentan y dedican la tragedia al rey, evocando la historia y la leyenda como objeto del género trágico - y, en concreto, de la tragedia que se va a representar-, el motivo de la celebración y los buenos augurios para las futuras empresas del joven Luis XIV. Como afirma Molinari14, Torelli tenía la habilidad de crear un espacio concreto y definido, pero que no daba la sensación de estar encerrado en los limitados confines del escenario. Era incluso capaz de crear, magistralmente, varios niveles espaciales de lejanía, como se puede apreciar en el primer grabado de Chauveau: un primer nivel, con los bastidores laterales de árboles, uno intermedio que, en realidad, sería el fondo físico de la perspectiva mediana que cierra el espacio practicable, con la gruta excavada en la montaña, y un tercer nivel al que se abre esta, un paisaje marino ${ }^{15}$. La gruta, por tanto, rompe la continuidad de la perspectiva de la selva, pero al focalizar en su abertura el paisaje marino, refuerza y amplía la falsa profundidad, funcionando casi como el arco que cierra la escena trágica serliana, detrás del cual se muestra la geometría infinita de las estructuras arquitectónicas, como en la siguiente escena urbana, que abre la tragedia y que representa la plaza pública de la ciudad capital del reino de Cefeo [Figura 6].

Los momentos escogidos por Chauveau para reproducir los decorados de cada uno de los cinco actos son aquéllos en los que aparecen la máquinas en las que se manifiestan las divinidades o se lleva a cabo la empresa del héroe elevado al rango de semidiós y, por tanto, con derecho a tramoya, mientras los mortales las contemplan maravillados; es decir, elige el momento culminante que mejor expresa el artificio escénico, como se ve en esta tercera escena del primer acto,

13 Ya en 1650 Corneille había publicado el Dessein de la tragédie d'Andromède, con el orden de las escenas y la descripción de los decorados y tramoyas del prólogo y los cinco actos. Guarino, 1982, p. 33.

14 Molinari, 1968, pp. 164-167.

15 «Le pied de cette montagne est percé à jour par une grotte profonde qui laisse voir la mer en éloignement. Les deux côtés du Théâtre sont occupés par une forêt d'arbres touffus et entrelacés les uns dans les autres». Corneille, Andromède [decorado del Prólogo], p. 11. 
cuando hace su aparición Venus en una estrella para anunciar con un ambiguo oráculo las bodas de Andrómeda, sin especificar el nombre del elegido ${ }^{16}$.

El decorado del segundo acto [Figura 7] es un jardín ameno que se caracteriza por su orden geométrico cuyos elementos construidos y artificiales dominan sobre la vegetación. Se convierte así el jardín en una variante de la escena trágica con elementos propios de la naturaleza pero ordenados arquitectónicamente, imitando arcos, templos y construcciones nobles. Encontramos de nuevo el telón de fondo que se abre al infinito, un arco formado por una sucesión de «naranjos en macetas", escribe Corneille, "que forman una admirable pérgola en mitad del teatro, dividiéndolo de esta forma en tres avenidas que gracias al artificio ingenioso de la perspectiva parecen tener más de mil pasos de longitud» ${ }^{17}$. Si comparamos esta escena con otra también figurando un jardín, ejecutada por Baccio del Bianco para la fábula escénica de Calderón de la Barca Andrómeda y Perseo [Figura 8], vemos que el escenógrafo toscano logra el mismo efecto de profundidad (pero sin esa misma necesidad de tener que subrayarla o enmarcarla que caracteriza las composiciones de Torelli), con el frondoso bosque pintado en el bastidor del foro como prolongación de la naturaleza combinada, a un lado, con fuentes y estatuas, y, al otro, con la arquitectura del palacio residencia de la Medusa, cuya cabeza exhibe triunfante Perseo mientras el caballo Pegaso, nacido de la sangre derramada de la gorgona, alza el vuelo atravesando el escenario.

En el jardín de la Andrómeda francesa [Figura 7], al final de la quinta escena, la máquina de Eolo y los ocho vientos rapta a la princesa para ofrecerla en sacrificio, como víctima elegida por los dioses, al monstruo que aterroriza el reino de Cefeo, anticipando el momento clave de la representación que tendrá lugar en el tercer acto, en el contexto escénico de la naturaleza salvaje como fondo de «la injusticia de los dioses y del suplicio de Andrómeda» [Figura 9], como se lee en la acotación correspondiente, es decir, donde tendrá lugar el

16 Guarini, 1982, p. 83.

17 «De chaque côté se détache un rang d'Orangers dans de pareils Vases, qui viennent former un admirable berceau jusqu'au milieu du Théâtre, et le séparent ainsi en trois allées, que l'artifice ingénieux de la Perspective fait paraitre longues de plus de mille pas». Corneille, Andromède [decorado del Acto II], p. 28. 
«horrible espectáculo» al que asisten desde la orilla la reina Casiopea junto a otros personajes ${ }^{18}$. Los bastidores laterales simulando las rocas enmarcan el campo de acción de la escena, mientras los personajesespectadores se concentran en el espacio practicable del proscenio, en primer plano, y al fondo se extiende un paisaje de lo que se supone que es una isla con su playa, que comprime un poco el decorado marino que preside el escenario, y que Corneille describe como un mar tan vasto y extenso que hacía creer que los bajeles que navegaban en el horizonte estaban a más de seis leguas de distancia ${ }^{19}$. Aunque la imagen no puede negar su carácter escenográfico, ya que se reconoce perfectamente la secuencia de los bastidores figurando las rocas, sin embargo el grabador no demuestra ningún interés en reproducir el artificio escénico de las olas marinas, sino que, como también hiciera Guitti, prefiere imitar el objeto real, es decir, el mar. Su finalidad, que es la misma que suele encontrarse en los dibujos y grabados con este tipo de reproducciones escénicas, era la de conservar el recuerdo del espectáculo e incluso la impresión o, más bien, el impacto visual que se buscaba en los espectadores. Seguramente el efecto final no resultaría tan perfecto y, de hecho, los testimonios gráficos de Guitti, Chauveau y Baccio del Bianco lo que ofrecían era «el resultado ideal de una realidad escénica» ${ }^{20}$.

El monstruo marino, que Guitti se inventaba con aspecto de monstruoso cetáceo [Figura 4], modelo que seguirá Baccio del Bianco, aquí [Figura 9] ofrece una imagen más tradicional de dragón con escamas que ya aparecía en una ilustración francesa [Figura 10] de Las Metamorfosis ovidianas, de 1564. Aunque la fisionomía de los dos monstruos sea distinta en Torelli y en Baccio del Bianco, uno más modelo ‘dragón', el otro más 'orca' o ‘ballena' fantástica [Figura 11], los dos escenógrafos utilizarán, como ya hiciera años atrás Guitti en Ferrara, el mismo efecto para la aparición en escena del monstruo y su avance amenazador hacia la princesa encadenada, lo que indicaría o un conocimiento por parte de Baccio de los espectáculos de 1638 y 1650 y, por supuesto, de los testimonios gráficos de Guitti y Chauveau, o un procedimiento usual entre los técnicos de la materia. Es intere-

18 Corneille, Andromède [decorado del Acto III], p. 44.

19 Corneille, Andromède, p. 44; Guarino, 1982, pp. 91-92.

${ }^{20}$ Bolduc, 2002, pp. 62-63. 
sante, de todas formas, la coincidencia de los testimonios escritos que dejaron el cronista de La Gazette de febrero de 1650 y Calderón en las acotaciones del manuscrito ilustrado con los dibujos de Del Bianco. Escribía Renaudot [Figura 9]: «... este terrible monstruo avanzaba poco a poco... y no sólo movía todo su cuerpo en el gran camino que iba trazando, sino también cada una de sus partes y, lo que es más notable en la perspectiva, parecía de diferentes tamaños a medida que se acercaba» ${ }^{21}$; y Calderón [Figura 11]: «... Se vio en el mar un monstruo que, empezando pequeño en lo último, a cada vuelta que daba atravesando las ondas, parecía mayor... A la última vuelta más cercana que dio el monstruo, salió tan grande y tan horrible, que hacía más tremendo el espectáculo de la fábula» ${ }^{22}$. Es decir, que se iba aproximando hasta la orilla desde el fondo, mostrándose cada vez más grande, efecto que todos coinciden en atribuir al 'milagro' de la perspectiva, aunque parece más verosímil que se emplearan varios modelos del monstruo con distintos tamaños ${ }^{23}$.

En esta segunda escena del tercer acto [Figura 9], momento cumbre de la tragedia de Corneille, Perseo hace su aparición a lomos del caballo Pegaso, empuñando un escudo y una espada con la que matará a la bestia, después de lo cual ordenará a los vientos que desaten a Andrómeda y saldrá de escena realizando una «cabriola admirable en mitad del aire» ${ }^{24}$. A diferencia de los Perseos de Ferrara y Madrid, el de París no usa la horrible cabeza para rematar al monstruo, sino sólo para eliminar al rival Fineo, episodio narrado en el quinto y último acto por un personaje, Phorbas, haciendo que, como en el caso de Ferrara, esta ulterior acción de Perseo no forme parte del discurso escénico o representativo sino narrativo. En Calderón el escudo con la imagen impresa de la gorgona sirve tanto en la lucha contra el mons-

21 El relator de la reposición editada en 1682 describía así la aparición de la bestia: «Se descubre, todo lo lejos que la vista pueda distinguir, un monstruo marino al fondo de la perspectiva; pero es tan grande la lejanía que a duras penas se podía reconocer su forma, de lo pequeño que era al principio. A medida que avanza se lo ve crecer, y no pasa mucho tiempo antes de que se pueda distinguir la horrible forma». Citados ambos en Bolduc, 2002, pp. 78-79.

22 Calderón de la Barca, Andrómeda y Perseo [Jornada III], p. 159.

23 Chaves Montoya, 2004, p. 212.

24 Corneille, Andromède [acotación escénica del Acto III, Escena 3], p. 53. 
truo como contra Fineo, suceso que tampoco se representa sino que se relata.

También sabremos por el propio Perseo, después de su victoria sobre el monstruo y una vez liberada Andrómeda, que es hijo de Júpiter $^{25}$, es decir, Corneille no hace uso de la analepsis como, sin embargo, hará Calderón, quien entrelaza las historias de Perseo y Andrómeda, lo que significa también que la acción se desarrollará en distintos lugares geográficos y en varios momentos, no en un sólo día como en la ópera-torneo de Ferrara y en la tragedia de Corneille. Calderón se toma varias licencias a la hora de reconstruir la fábula de Andrómeda y Perseo, alejándose en ocasiones del relato ovidiano, como también hiciera el dramaturgo francés. El español introducirá muchos cambios, aportando de su inventiva numerosos elementos que enriquecían dramáticamente la trama y la acción, y ofrecían más posibilidades tanto al contenido como a la forma, ya que los episodios y los lugares de acción se multiplican, los diálogos se suceden sin tregua e incluso los largos monólogos carecen de la rigidez solemne de los versos de Corneille, si bien éste hizo no pocas concesiones para adaptarse al estilo del nuevo género de espectáculo conocido como tragédie à machines.

El cuarto acto de Andromède es bastante estático, una especie de pausa en la que no sucede nada especialmente significativo ni desde el punto de vista dramático ni desde el visual. Andrómeda acepta al vencedor como futuro marido, y Fineo recibirá el apoyo de Juno, que, al final de la cuarta escena [Figura 12], recorrerá desde lo alto, en su carro tirado por dos pavos reales, el vestíbulo o salón - flanqueado por arquerías con columnas adosadas y estatuas sobre pedestales- del palacio real destinado a la celebración de las bodas de Andrómeda y Perseo, para manifestar su aversión hacia el hijo de su infiel marido Júpiter. También en esta ocasión Torelli amplía el espacio del escenario abriendo tres puertas en el frontispicio a través de las cuales se distinguen «tres alamedas de cipreses» que se extienden «hasta perderse de vista» ${ }^{26}$.

La última mutación escénica [Figura 13], correspondiente al quinto acto - muy sutil pues básicamente conserva la estructura y la com-

25 Corneille, Andromède [Acto III], vv. 966-969.

${ }^{26}$ Corneille, Andromède [decorado del Acto IV], p. 56. 
posición del anterior decorado ${ }^{27}$-, muestra la galería porticada con columnas que precede al templo en cuyo interior se está preparando el sacrifico a Júpiter. Aquí se cierra la tragedia con la apoteosis de los dioses reconciliados, con Júpiter presidiendo el cielo en su trono «brillante de oro y luces», y en la nube a su derecha Juno, que ha recibido a Perseo y al rey, y en la de la izquierda Neptuno, flanqueado por Andrómeda y la reina, para celebrar en los cielos las bodas de los dos jóvenes, destinados a transformarse en las constelaciones que llevan sus nombres.

Con una apoteosis y gloria de dioses y la transformación de los protagonistas en sus homónimas constelaciones, concluía igualmente, según las convenciones de las comedias de aparato de la época, el espectáculo con texto de Calderón de la Barca y escenografía del ingeniero y escenógrafo toscano Baccio del Bianco Fortunas de Andrómeda $y$ Perseo [Figura 14], fábula escénica dividida en una loa, heredera de los prólogos italianos, como en la Andromède francesa, y tres actos, que se estrenó en el Coliseo del Buen Retiro de Madrid el 18 de mayo de $1653^{28}$. No cabe duda de que Calderón y Del Bianco conocían la obra de Corneille y, por supuesto, los grabados de Chauveau con las escenas de Torelli. Desde luego, resulta evidente la proximidad formal de las dos representaciones, la francesa de 1650 y la española de 1653, ambas producto de una muy similar concepción dramático-espectacular. En efecto, en ambos casos la grandiosa escenografia a la italiana cautivó la atención de los asistentes y fue la principal responsable del éxito. También la pieza de Calderón-Del Bianco fue, como afirmó Corneille de la suya propia, un espectáculo creado «sólo para los ojos», e, igualmente, como en el caso francés, los efectos escénicos eran tan necesarios que, como insistía Corneille, «no se podía eliminar ninguno sin que se derrumbara todo el edificio» ${ }^{29}$.

27 «L'art du sieur Torrelli est ici d'autant plus merveilleux qu'il fait paraître une grande diversité en ces deux décorations, quoiqu'elles soient presque la même chose». Corneille, Andromède [decorado del Acto V], p. 70.

${ }^{28}$ Margaret R. Greer dedicó el segundo capítulo de su libro The Play of Power a las reelaboraciones que Lope de Vega, Corneille y Calderón de la Barca hicieron de la fábula de Andrómeda, titulado "Calderón, Master of Polyphony: Las fortunas de Andrómeda y Perseo", cuya aportación resulta fundamental para el argumento aquí tratado. Greer, 1991, pp. 31-76.

29 Corneille, Andromède [Argumento], pp. 8-9. 
Corneille presentaba a Perseo como un caballero andante y Calderón, aunque no lo dice explícitamente, también trata como tal al personaje, cuyo recorrido aventurero, con todas las empresas superadas, le permitirán llegar a la última, gracias a la cual conquistará el corazón y la mano de la bella Andrómeda. Una de las diferencias sustanciales la proporciona el propio título, es decir, no se habla sólo del episodio del monstruo que aterrorizaba las costas del reino de Cefeo, la condena y la liberación de la princesa Andrómeda, sino que Fortunas de Andrómeda y Perseo alude a su historia común pero también narra la identidad del héroe, hijo de Júpiter y Dánae, el modo en que Morfeo le informará de sus orígenes y las circunstancias que acompañaron su concepción en esa analepsis de la que hablé antes, así como las aventuras que precedieron la empresa decisiva que demostrará la verdadera identidad semidivina de Perseo.

Esta aventura, como es bien sabido, se lleva a cabo en un decorado marino [Figura 11] y es precisamente la escena que más similitudes presenta con la de Torelli, aunque Baccio del Bianco deja un espacio mucho más amplio y despejado en primer plano, donde se situaban los actores, aquí espectadores de la lucha de Perseo contra el monstruo, y no constriñe con los bastidores el espacio del mar, verdadero marco de la acción, como había hecho Torelli. El toscano divide el escenario en dos partes: "el primer término" de bastidores, como describía la acotación, que figuraba «peñas brutas, sembradas de conchas, caracoles y corales, [...] y el segundo término, de escollos sobre las ondas apenas descubiertos ${ }^{30}$. Andrómeda aparece encadenada en un promontorio que sobresale del resto de las rocas, según ese modelo ya propuesto por Callot y seguido por Guitti en Ferrara. Perseo monta el caballo alado empuñando lanza y escudo (que en el dibujo de Del Bianco no se distingue), en la iconografia de la aventura más cercana, de las hasta ahora vistas, a la ariostesca del salvamento de Angélica por Ruggiero y a la elegida por Rubens para representar su Andrómeda libertada por Perseo [Figura 15], cuadro completado por Jordaens en 1640, para el Salón de los Espejos del Alcázar Real de Madrid, en el que se ve a un caballero con armadura (Perseo) mientras desata a una joven (Andrómeda), a cuyos pies ha dejado el escu-

${ }^{30}$ Calderón de la Barca, Andrómeda y Perseo [Jornada III], p. 150. 
do con la cara impresa de Medusa, y un caballo blanco alado (Pegaso) al fondo de la composición, vuelto hacia la orilla.

El pasaje a la siguiente y última mutación se producía paulatinamente [Figura 14]. En el foro descendía una fachada de templo coronado por un cúpula gallonada, decorada con volutas, a la vez que los bastidores laterales de rocas se retiraban para dar paso a una galería de columnas pareadas alternando con estatuas, correspondientes, según la acotación, a un palacio real. Baccio del Bianco compuso un espacio arquitectónico de órdenes clásicos que tiene algo de versión sintetizada de los dos últimos decorados de Torelli [figuras 12 y 13]. Sobre la fachada del templo se extiende un coro de dioses con instrumentos musicales, Júpiter y su corte, que han aparecido en el cielo entre nubes, "de suerte que a un tiempo se vio este teatro [...] con un templo, un palacio, un cielo y unas deidades en el ayre, y la gente del tablado...», como rezaba la relativa acotación ${ }^{31}$.

En esta última escena hacían también su aparición sobre nubes en alto, acompañados por la música y el canto, Juno y la Discordia a un lado, y Mercurio y Palas al otro. Mientras las primeras reconocen su fracaso al intentar obstaculizar de todas las maneras posibles las acciones de Perseo, los segundos defienden la utilidad del caduceo y del escudo, que habían entregado al héroe y que lo habían ayudado a triunfar en sus empresas, como instrumentos de esa "divina voluntad». Si la obra de Corneille seguía la preceptiva de la tragedia clásica, en la que lo ineluctable del destino, marcado por los dioses, movía los hilos de la trama y su inevitable resolución, Calderón no niega a los hombres la libertad de sus acciones, ayudados, eso sí, por la divinidad que pone a su disposición los medios para poder llevar a cabo sus empresas por difíciles que éstas sean, según un principio mucho más acorde con la cultura católica.

En cuanto a la elaboración dramática de la fábula de Calderón, hay quienes, como Valbuena Briones o Martin, la relacionaban con El Perseo o La fábula de la bella Andrómeda y Perseo, la tragicomedia de Lope de Vega escenificada por encargo del duque de Lerma en Ventosilla, en 1613, ante Felipe III y sus hijos, la infanta Ana y el príncipe

31 Calderón de la Barca, Andrómeda y Perseo [Jornada III], p. 169. 
Felipe $^{32}$. En efecto, la fiesta del Coliseo coincide con la de Lope en los nombres de varios de sus personajes, incluso secundarios, y en algunos episodios, como los tres principales en torno a los cuales se articula la trama, la concepción del personaje de Perseo y las dos aventuras, con Medusa y el monstruo marino, aunque Lope sigue mucho más fielmente la fábula original. Pero Calderón, independientemente de las convenciones iconográficas, sacó también bastantes ideas de la tragedia de Corneille, reinterpretándolas en su composición; de hecho, el espectáculo de Madrid debe sin duda mucho más al de París desde el punto de vista argumental y visual que a ningún otro ${ }^{33}$.

Respecto al drama de Calderón, la tragedia de Corneille está mucho más comprimida, emplea menos personajes y elementos narrativos, es menos compleja dramáticamente, pues, como él mismo reconoce, se trató principalmente de un espectáculo visual. También el de Calderón goza de la misma espectacularidad visual y escénica, pero la historia está más elaborada y en ella se suceden muchos más episodios que en la del dramaturgo francés, al estar ambientados en distintas localizaciones geográficas y narrados en distintos tiempos, lo que además permitió a Baccio del Bianco diseñar un mayor número de decorados que Torelli. Corneille, en cambio, concentró la acción en un solo día, y, si no respetó rigurosamente la unidad de espacio al dividir la acción en varios lugares de la corte de Cefeo, se debió a una concesión o, más bien, a una exigencia que le obligaba a introducir las mutaciones escénicas que justificaban la creación de esta pièce à machines.

Aún así, es innegable la evidencia de que Calderón conocía el texto de Corneille, y Del Bianco, a través de los grabados de Chauveau, las escenas de Torelli, ya que también es más que probable que poseyeran o hubieran tenido ocasión de consultar un ejemplar de la edición de 1651, copia que llegaría a manos de Felipe IV enviada por su hermana Ana de Austria — según la arraigada costumbre de inter-

${ }^{32}$ Valbuena Briones, 1987; Martin, 1926, pp. 408-412. Sobre la escenificación de 1613 de El Perseo o La fábula de la bella Andrómeda y Perseo, de Lope de Vega, ver también Ferrer Valls, 1991, pp. 144-167 y Ferrer Valls, 1993.

33 Martin incluso hablaba de una analogía estructural entre ambas (Martin, 1926, pp. 408-411). Esta afirmación resulta un poco drástica si no excesiva, ya que en realidad sólo coinciden en algunos personajes y situaciones, sobre los que ya trató de forma amplia y exhaustiva el citado erudito en su artículo de 1926. 
cambiarse relaciones, textos dramáticos e imágenes de sus espectáculos entre los miembros emparentados de las realezas europeas- y que los autores tuvieron muy presente a la hora de concebir y construir la trama y la puesta en escena de las Fortunas de Andrómeda y Perseo. 


\section{BiBLIOGRAFÍA}

Bianconi, L., «Illusione e simulazione: La Finta Pazza», en Giacomo Torelli. L'invenzione scenica nell'Europa barocca, ed. F. Milesi, Fano, Fondazione Cassa di Risparmio di Fano, 2000, pp. 77-87.

Bolduc, B., Andromède au rocher. Fortune théâtrale d'une image en France et in Italie (1587-1712), Firenze, Leo S. Olschki Editore, 2002.

Bjurström, P., Giacomo Torelli and Baroque Stage Design, Stockholm, Almqvist \& Wiksell, 1962.

Brown, J., Imágenes e ideas en la pintura española del siglo XVII, Madrid, Alianza Forma, 1988.

Calderón de la Barca, P., Fortunas de Andrómeda y Perseo, en Obras completas, II, ed. Á. Valbuena Briones, Madrid, Aguilar, 1987, pp. 1639-1680.

- Andrómeda y Perseo. Fabula representada en el Coliseo del Real Palacio de Buen Retiro [1653], ed. R. Maestre, Almagro, Museo Nacional del Teatro, 1994.

Chaves Montoya, M. T., El espectáculo teatral en la corte de Felipe IV, Madrid, Ayuntamiento de Madrid / Área de Gobierno de las Artes, 2004.

- «Una fábula escénica para el cardenal Antonio Barberini: Il Palazzo incantato (1642) de Giulio Rospigliosi», en La comedia de caballerías, ed. F. B. Pedraza Jiménez, E. E. Marcello y R. López Cañal, Almagro, Universidad de Castilla-La Mancha, 2006, pp. 179-204.

Christout, M.-F., Giacomo Torelli. L'invenzione scenica nell'Europa barocca, ed. F. Milesi, Fano, Fondazione Cassa di Risparmio di Fano, 2000, pp. 194204.

Corneille, P., Andromède, tragédie représentée avec les Machines sur le Théâtre Royal de Bourbon, Rouen, Laurens Maurry, 1651.

Ferrer Valls, T., La práctica escénica cortesana: de la época del emperador a la de Felipe III, London, Tamesis Books Limited, 1991.

- Nobleza y espectáculo teatral. Estudio y documentos (1535-1622), Valencia, Universidad de Valencia / UNED / Universidad de Sevilla, 1993.

Gaeta Bertelà, G. y Petrioli Tofani, A., Feste e apparati medicei da Cosimo I a Cosimo II, Firenze, Gabinetto Disegni e Stampe degli Uffizi, XXXI, 1969.

Greer, M. R., The Play of Power. Mythological court dramas of Calderón de la Barca, Princeton, Princeton University Press, 1991.

Guarino, R., La tragedia e le machine. "Andromède» di Corneille e Torelli, Roma, Bulzoni, 1982.

López Torrijos, R., La mitología en la pintura española del Siglo de Oro, Madrid, Cátedra, 1985.

- «Las pinturas de Becerra en el palacio de El Pardo y la iconografía de Perseo y Pegaso", en Cinco siglos de arte en Madrid (XV-XX), Madrid, CSIC, 1991, pp. 263-271. 
Mamone, S., "Parigi, Loti, Callot, Cicognini et Adimari: Andromède dans le spectacle florentin au temps de Cosme II", en Andromède ou le héros à l'épreuve de la beauté, Paris, Klincksieck, 1996, pp. 511-557.

Martin, H. M., "Corneille's Andromede and Calderon's Las Fortunas de Perseo», Modern Philology, 4, 1926, pp. 407-415.

Molinari, C., Le nozze degli dèi, Roma, Bulzoni, 1968.

Pio di Savoia, A., L'Andromeda. Cantata e combattuta in Ferrara il Carnevale dell'anno 1638, Ferrara, s. e., 1639.

Portús Pérez, J., «Difusión y transformaciones de un tema clásico en el Siglo de Oro: la liberación de Andrómeda", Cuadernos de Arte e Iconografía, 2, 4, Madrid, Fundación Universitaria Española, 1989, pp. 84-92.

Povoledo, E., «Una rappresentazione accademica a Venezia nel 1634», en Studi sul teatro veneto fra Rinascimento ed età Baroca, ed. M. T. Muraro, Firenze, Leo S. Olschki Editore, 1971.

Ruiz de Elvira, A., Mitología clásica, Madrid, Gredos, 1988.

Strong, R., Arte y Poder (fiestas del Renacimiento. 1450-1650), Madrid, Alianza Forma, 1988.

Valbuena Briones, Á., "Nota preliminar de Fortunas de Andrómeda y Perseo», en P. Calderón de la Barca, Obras completas, II, ed. Á. Valbuena Briones, Madrid, Aguilar, 1987, pp. 1639-1640.

Williams, W., “"For Your Eyes Only”: Corneille's View of Andromeda», Classical Philology, 1, 2007, pp. 110-123. 


\section{ILUSTRACIONES}

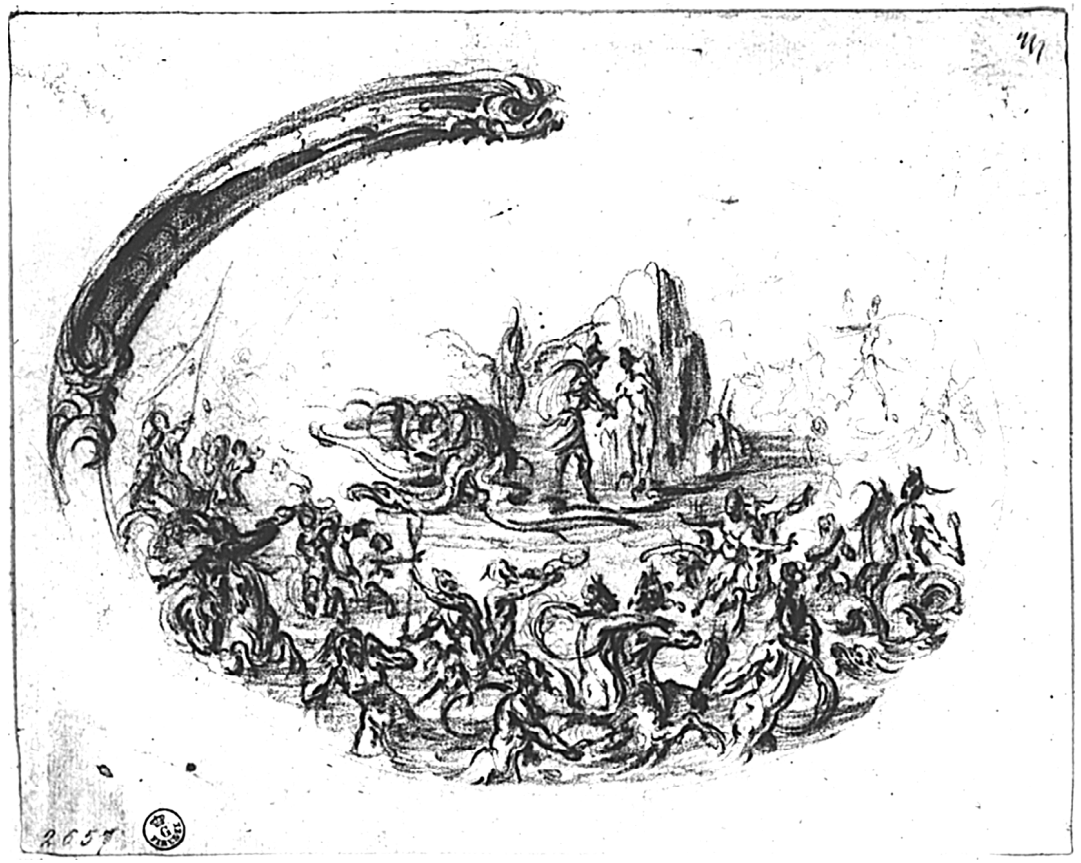

Figura 1: Jacques Callot, hipotético dibujo preparatorio para L'Andromeda de J. Cicognini (1618), Firenze, Gabinete de Dibujos y Estampas de los Uffizi, núm. 2657 F 


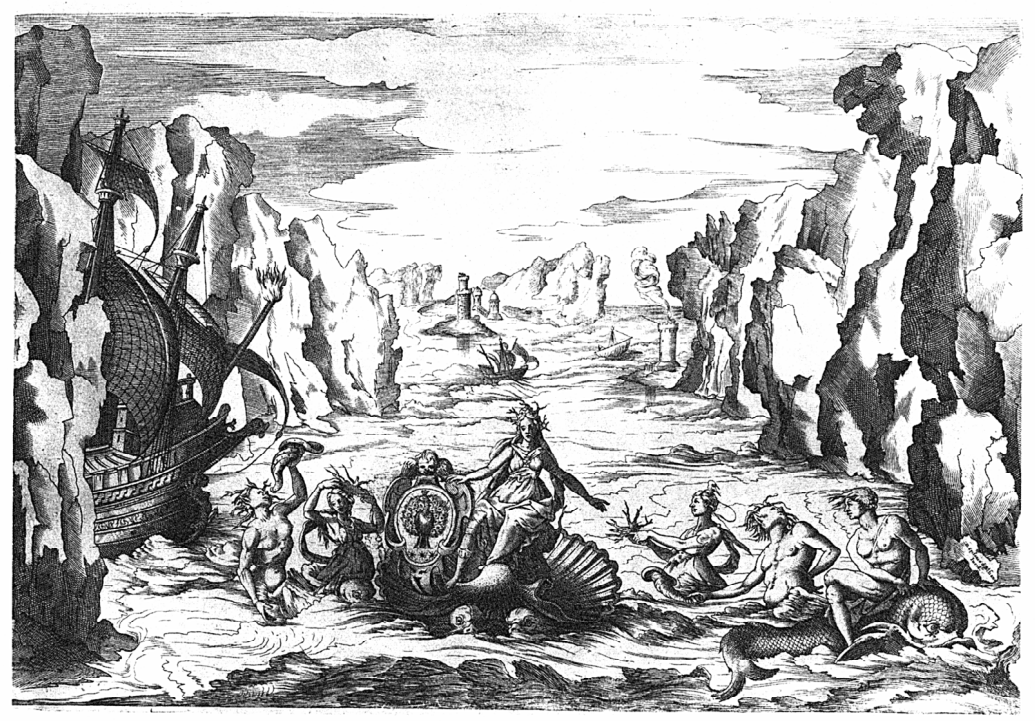

Figura 2: Bernardo Buontalenti, El rescate de Arión (1592), V intermedio de La Pellegrina (1589), grabado de Epifanio d'Alfiano 


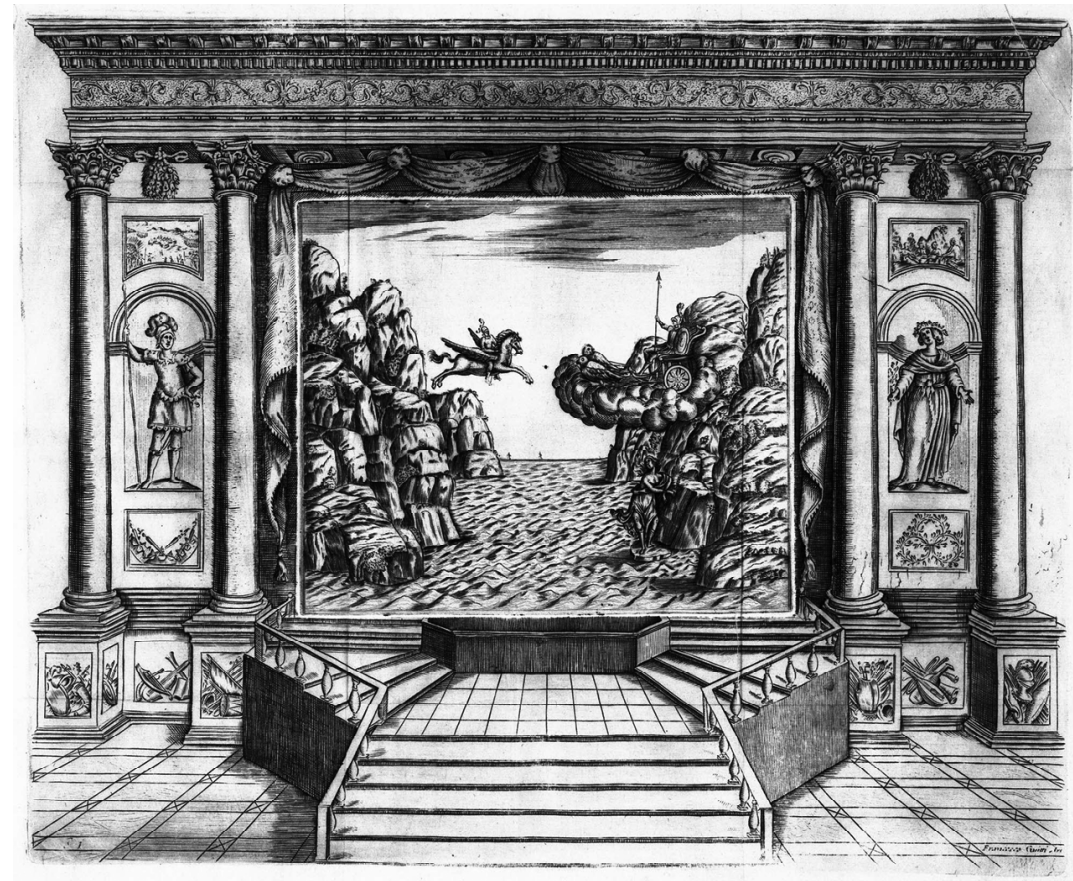

Figura 3: Francesco Guitti, Andrómeda encadenada, escena de L'Andromeda (1639) de Acanio Pio di Savoia, grabado 


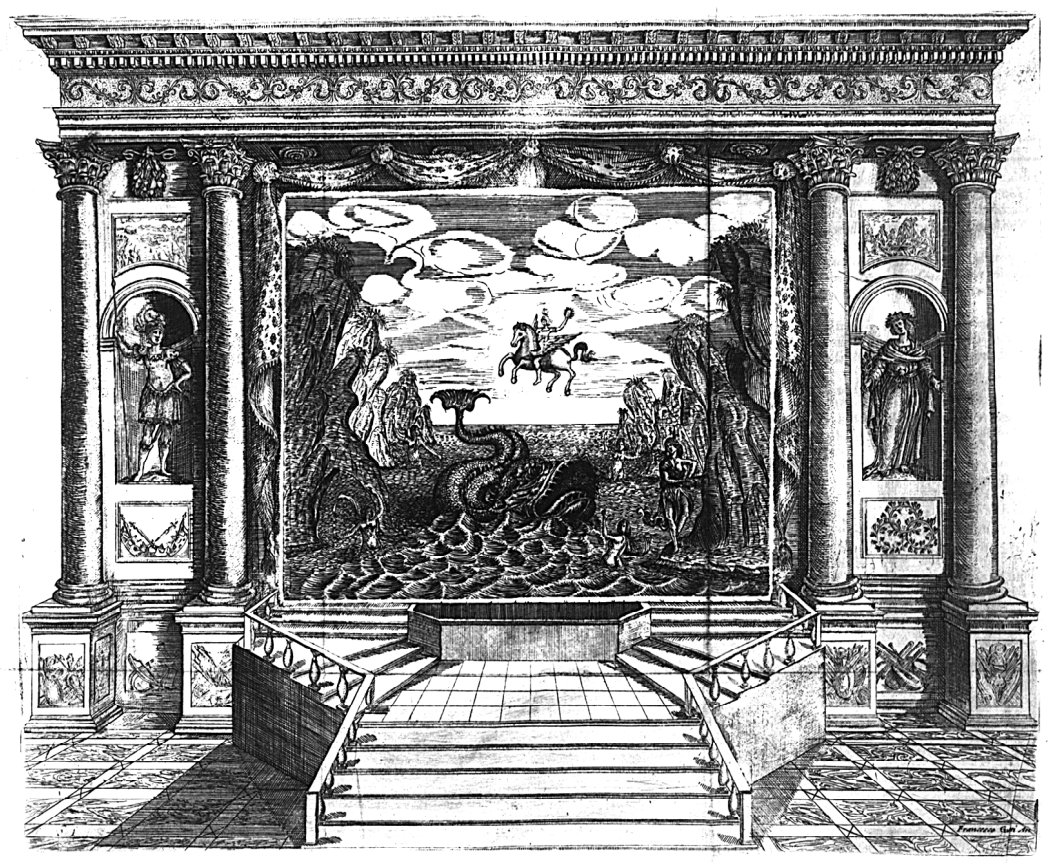

Figura 4: Francesco Guitti, Liberación de Andrómeda, escena de L'Andromeda (1639) de Ascanio Pio di Savoia, grabado 


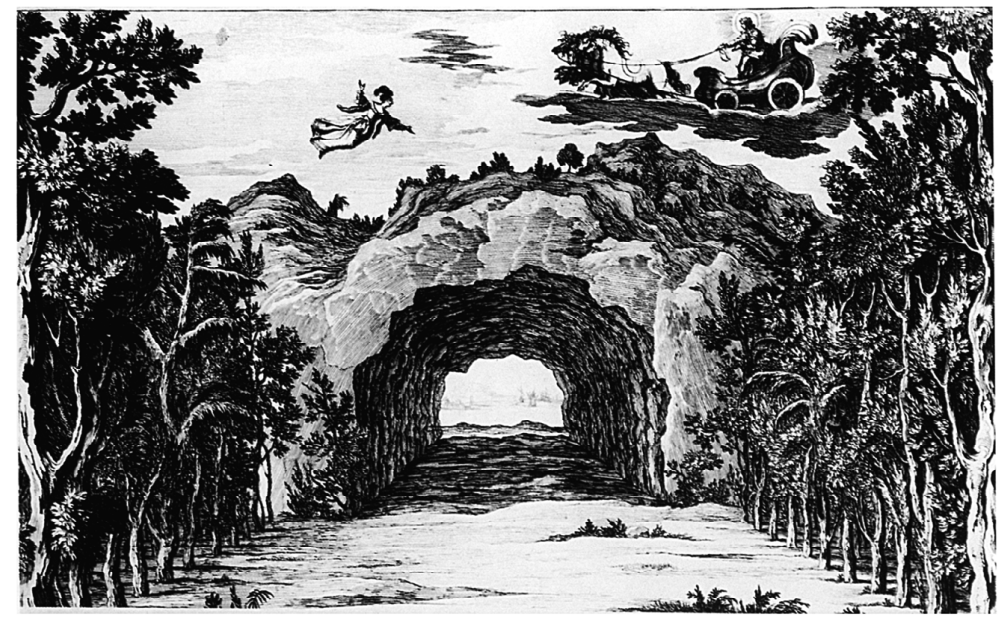

Figura 5: Giacomo Torelli, "Prólogo» de Andromède (1651) de Pierre Corneille, grabado de François Chauveau 


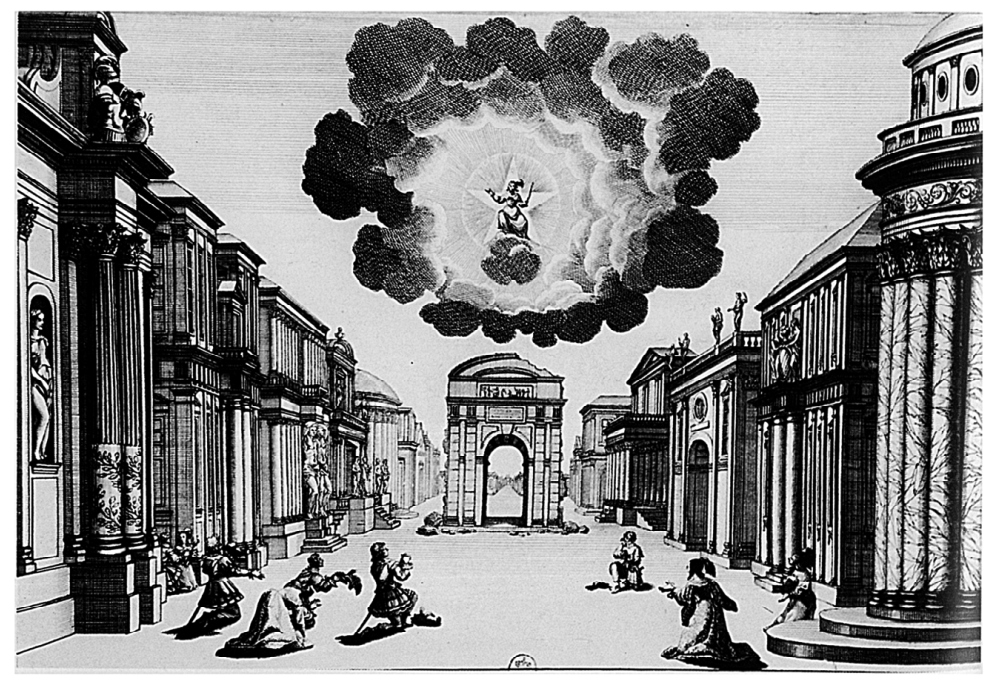

Figura 6: Giacomo Torelli, Escena 3 del Acto I de Andromède (1651) de Pierre Corneille, grabado de François Chauveau 


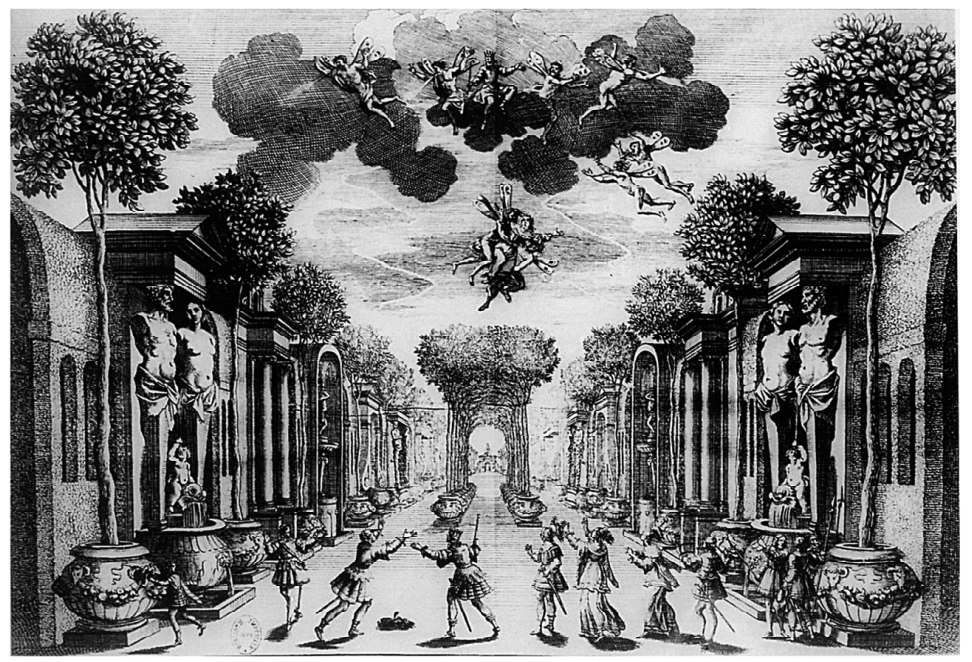

Figura 7: Giacomo Torelli, Escena 5 del Acto II de Andromède (1651) de Pierre Corneille, grabado de François Chauveau 


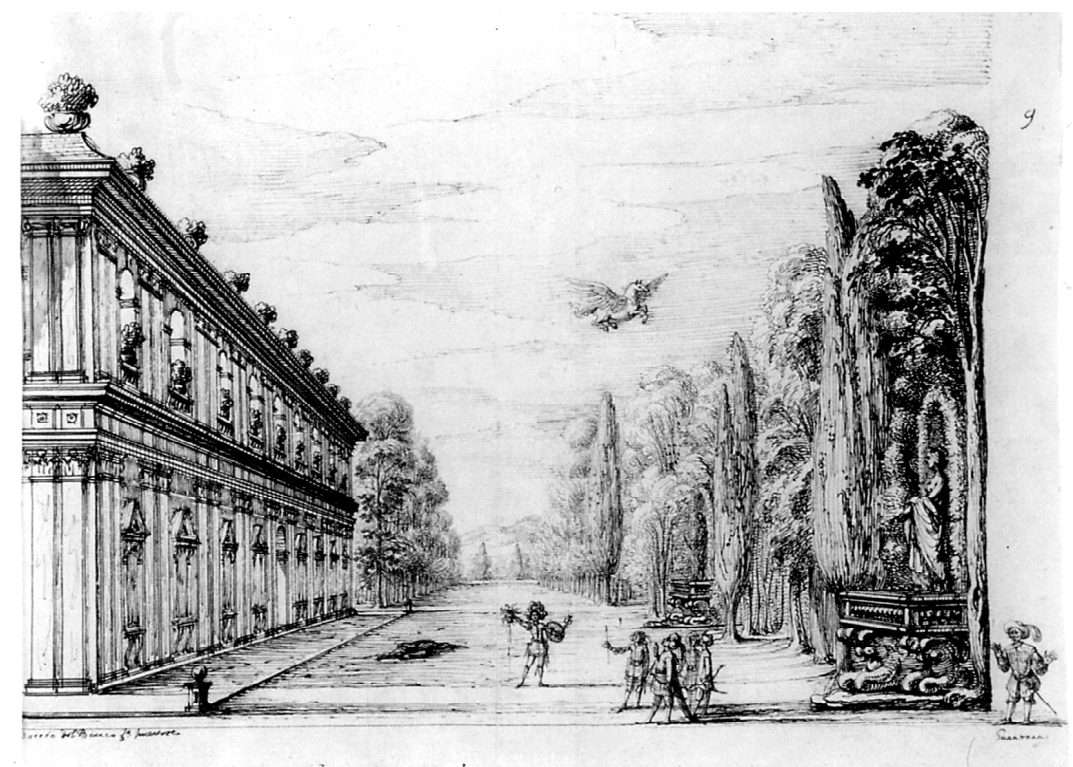

Figura 8: Baccio del Bianco, Palacio de Medusa, Jornada III de Andrómeda y Perseo (1653), dibujo, Cambridge (Mass.), Harvard University, The Houghton Library 


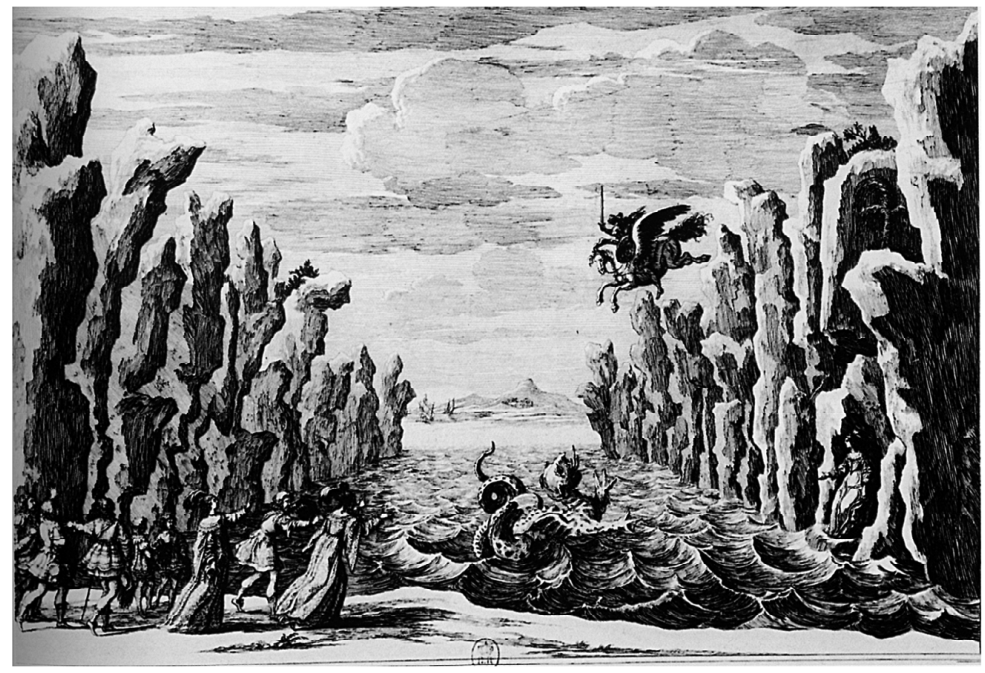

Figura 9: Giacomo Torelli, Escena 3 del Acto III de Andromède (1651) de Pierre Corneille, grabado de François Chauveau 


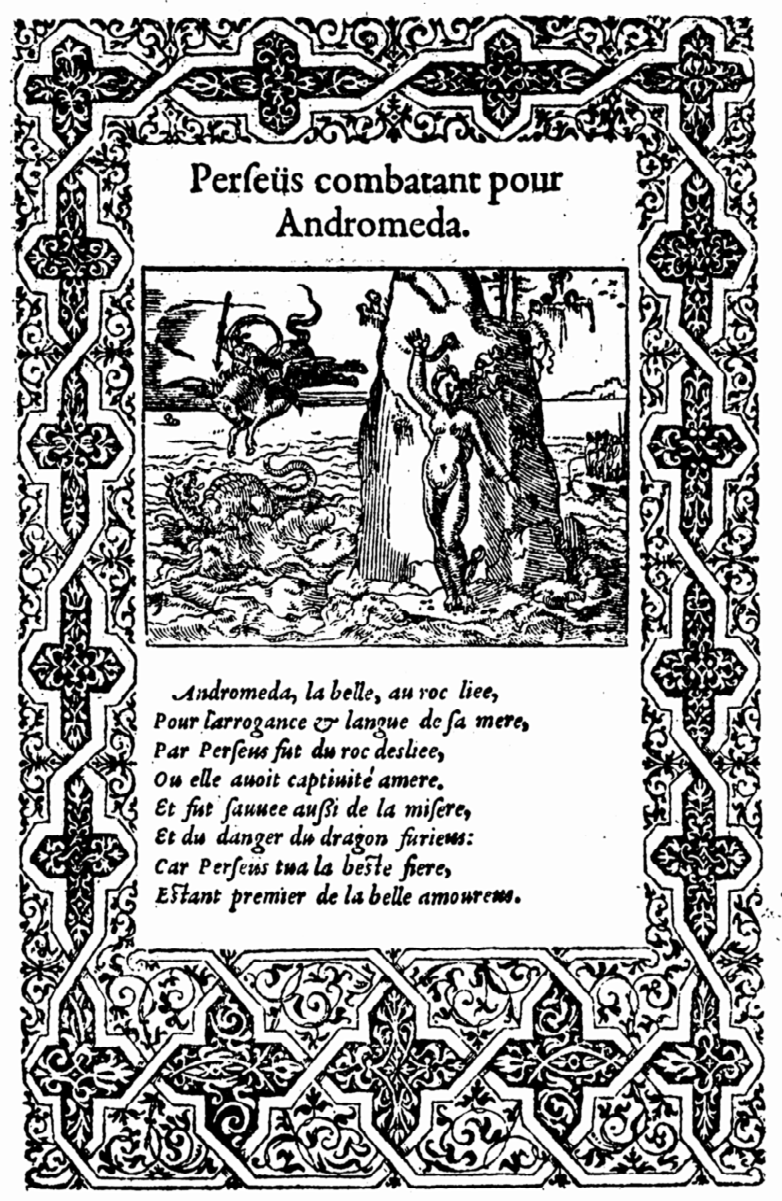

Figura 10: Anónimo, Perseüs combatant pour Andromeda, de La Metamorphose d'Ovide figurée (1564), grabado 


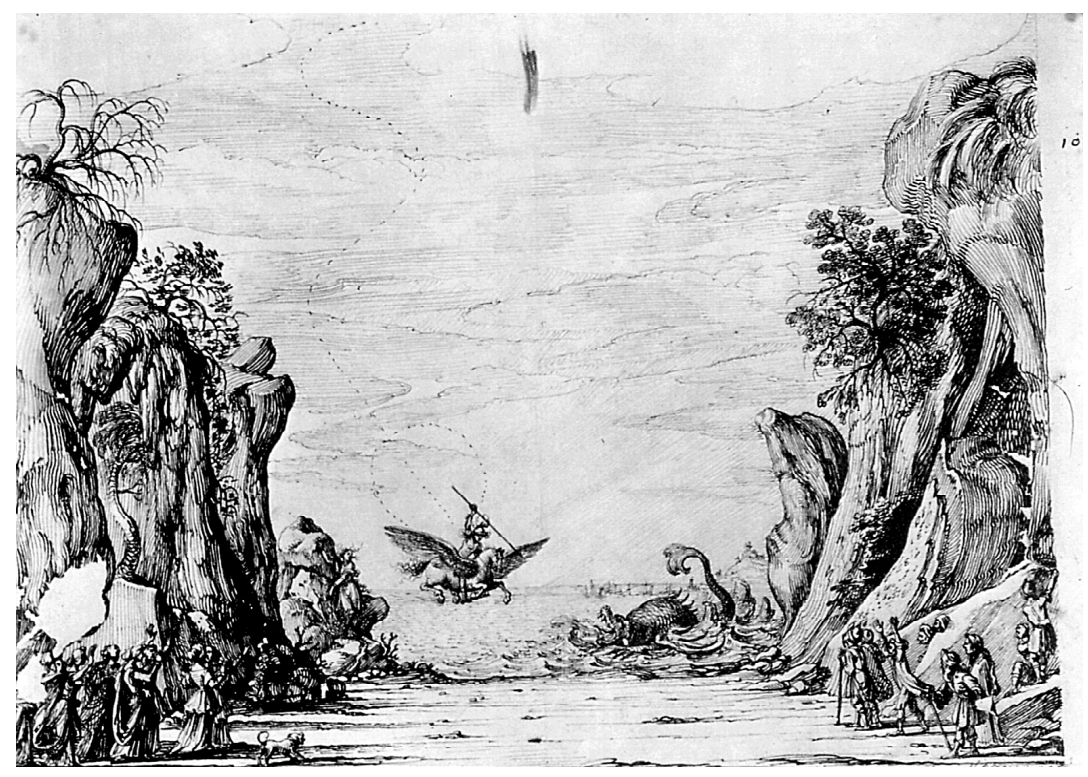

Figura 11: Baccio del Bianco, Liberación de Andrómeda, Jornada III de Andrómeda y Perseo (1653) de Calderón de la Barca, dibujo, Cambridge (Mass.), Harvard University, The Houghton Library 


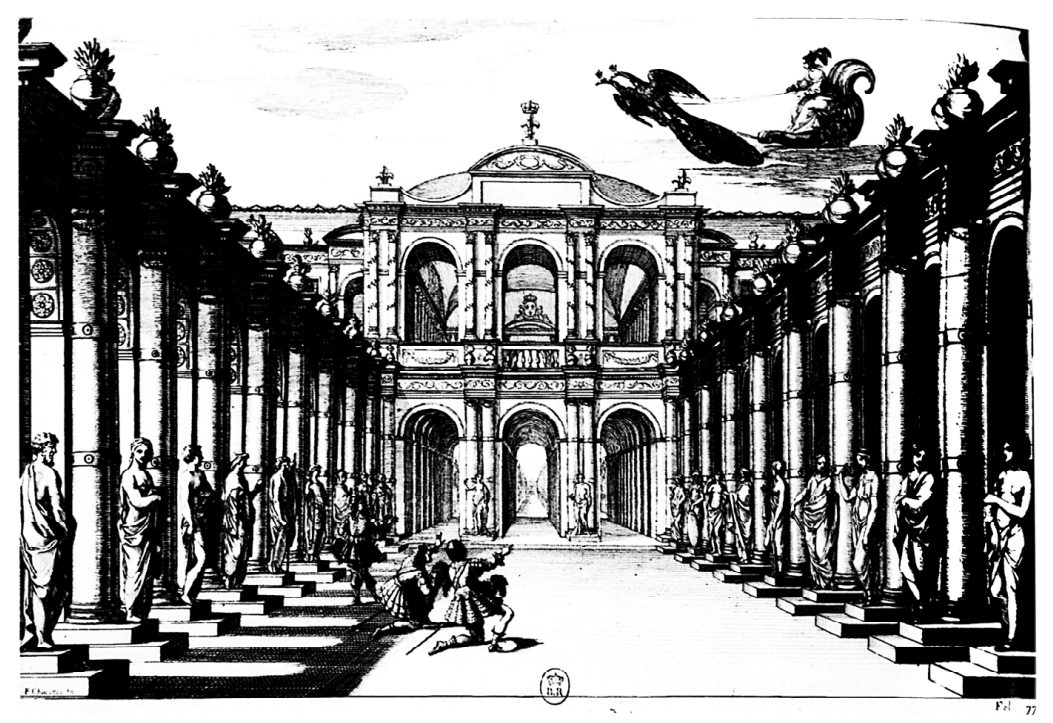

Figura 12: Giacomo Torelli, Escena 4 del Acto IV de Andromède (1651) de Pierre Corneille, grabado de François Chauveau 


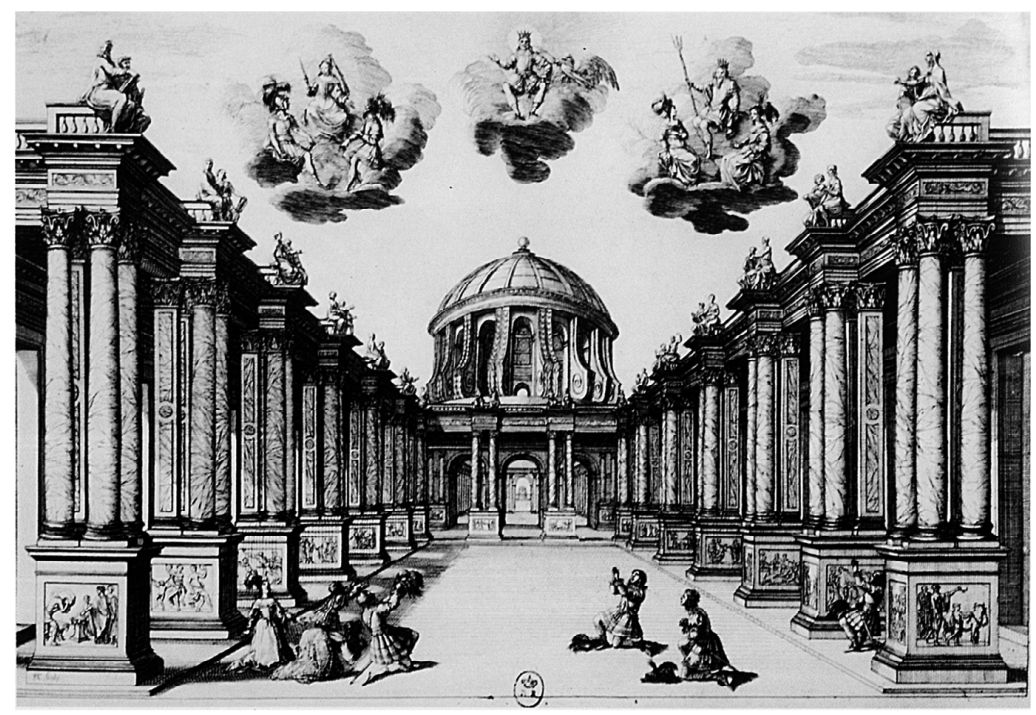

Figura 13: Giacomo Torelli, Escena 8 del Acto V de Andromède (1651) de Pierre Corneille, grabado de François Chauveau 


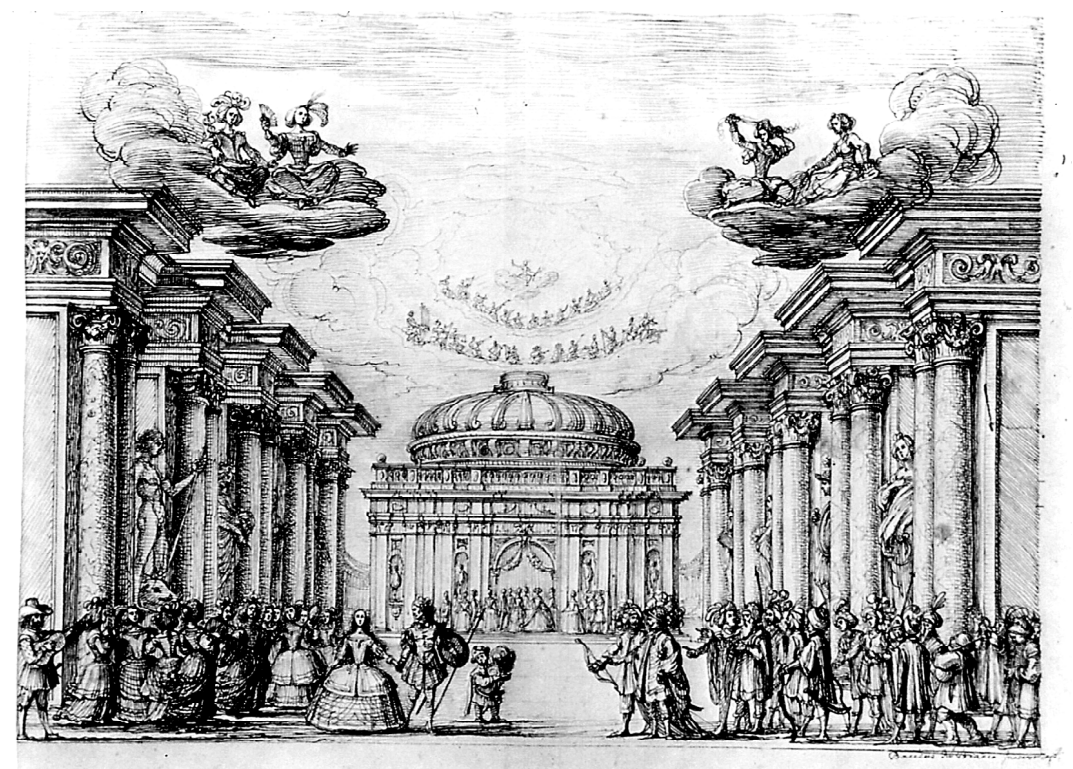

Figura 14: Baccio del Bianco, Apoteosis final, Jornada III de Andrómeda y Perseo (1653), dibujo, Cambridge (Mass.), Universidad de Harvard, The Houghton Library 


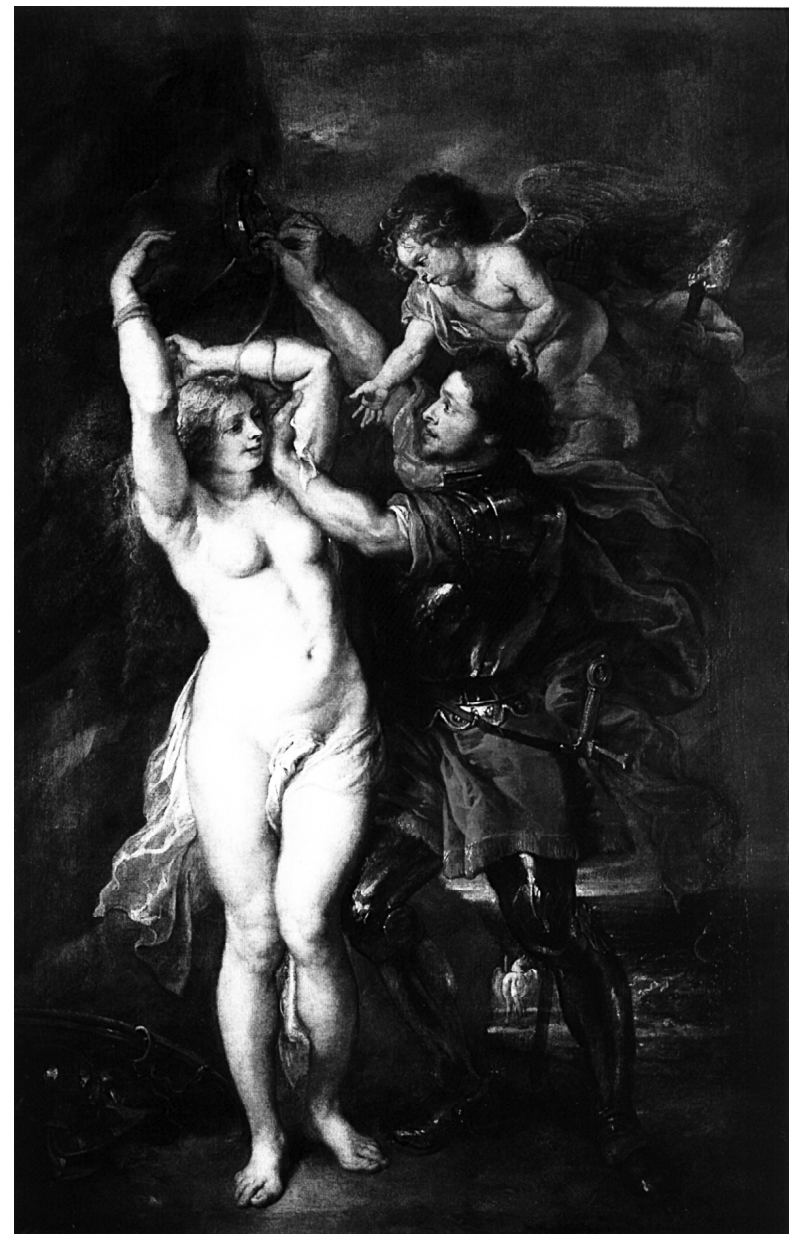

Figura 15: Rubens, Andrómeda libertada por Perseo, óleo sobre lienzo, Madrid, Museo del Prado 